\title{
Urban Tourism and Evolutionary Economic Geography: Complexity and Co-evolution in Contested Spaces
}

\author{
Patrick Brouder • Dimitri Ioannides
}

Published online: 21 October 2014

(C) Springer Science+Business Media Dordrecht 2014

\begin{abstract}
Urban tourism is an important research topic whether in mass tourism resort areas where tourism is the economic staple or in metropolitan areas where it is one (or more) development path(s) among many. Urban areas are dynamic and fast-paced environments but are also places where social and economic inequalities are most stark. Economic geography is one theoretical perspective through which researchers address urban tourism. The recent "evolutionary turn" in economic geography is finding its way to tourism studies but has only been applied to a few urban tourism cases. This paper sets out the potential of evolutionary economic geography (EEG) as a conceptual framework for urban tourism studies. The analysis draws on recent studies of urban tourism from an evolutionary perspective to highlight the strengths of taking such an approach and a number of avenues yet to be explored are put forward. Urban tourism affects large numbers of residents and businesses as well as influencing labour flows, and so understanding the dynamic nature of its development paths is vital. Tourism development does not occur in a vacuum, and urban tourism is one area where the complexity of the tourism economy and its place within broader regional development strategies is most obvious. Under recent neoliberal policies of urban development, tourism has become closely associated with place-based competition and large capital investments. Urban tourism also enters the fray in matters of contested urban spaces with issues of local governance, such as privatisation of public space, moving increasingly to the fore. The paper concludes with a list of future approaches to evolutionary studies of urban tourism to broaden the scope beyond the dominant financial metrics of tourism success.
\end{abstract}

P. Brouder $\cdot$ D. Ioannides

Department of Tourism Studies \& Geography, Mid Sweden University, Östersund, Sweden

P. Brouder

School of Tourism and Hospitality, University of Johannesburg, Johannesburg, South Africa

P. Brouder $(\bowtie)$

Department of Geography, Brock University, St Catharines, Canada

e-mail: pbrouder@brocku.ca

D. Ioannides

Department of Geography, Geology, and Planning, Missouri State University, Springfield, MO, USA 
Keywords Complexity Co-evolution - Evolutionary economic geography - Tourism • Urban

\section{Introduction}

Cities have long been major foci of global tourist flows (Hoffman et al. 2004). Especially over the last quarter century or so, numerous cities throughout the world, from major metropolitan regions down to small market towns, have immersed themselves in a global tug-of-war whereby they actively compete to attract visitors, especially to their central areas (Beauregard 1998; Judd and Fainstein 1999; Fainstein et al. 2004; Gotham 2006; Ioannides, D., \& Petridou E. Contingent neoliberalism and urban tourism in the United States. In J. Mosedale (Ed.) Neoliberalism and tourism: projects, discourses and practices. London: Ashgate, in press). As Fainstein et al. (2004: 1) point out, "urban regimes have especially focused on the competition for tourists because, unlike other economic sectors where central cities lose out to peripheral areas, in the case of tourism, the urban core dominates the metropolitan area."

Given the growing importance of tourism within urban areas, an expanding body of scholarship has emerged on the topic since the mid-1990s when Page (1995) first mentioned that research on city-based tourism was, at best, sketchy and suffered from theoretical gaps (Judd and Fainstein 1999). There now exists a solid body of literature relating to city-based tourism (cf. Ashworth and Page 2011) with explorations ranging, for example, from discussions about the transformation of cities from centres of cultural to creative consumption (Richards and Wilson 2007) to the use of regulation theory to comprehend the workings of urban tourism (Fainstein et al. 2004).

One aspect about urban tourism is that when dealing with metropolitan regions, especially those with extremely diffuse economies, this sector emerges as only one of several development paths. In fact, tourism development never occurs in a vacuum and urban tourism is one issue where the complexity of the tourism economy and its place within broader regional development strategies is most obvious. The co-evolution of the various tourism paths in urban areas is especially complex and so too is the interaction of the various tourism paths with other regional economic developments (cf. Brouder 2014a). For instance, urban tourism enters the fray in matters of contested urban spaces with issues of local governance, such as privatisation of public space, moving increasingly to the fore. In urban regions of varying scales, tourism can have an effect, for instance, on a large number of residents while also influencing the geography of work and workers (Tufts 2006; Zampoukos and Ioannides 2011) as well as local businesses.

This ultimately means that understanding the dynamic nature of tourism's development is especially vital, and to achieve this, it is useful to utilise economic geography as a key theoretical perspective (Ioannides and Debbage 1998, 2014). Specifically, the recent "evolutionary turn" in economic geography, which has begun finding its way into tourism studies, provides a useful lens for exploring the sector's dynamic nature as has already been demonstrated in a small number of studies (e.g. Brouder and Eriksson 2013a; Gill and Williams 2014). Researchers addressing such matters in mature urban tourism destinations, as well as more recently emerging and expanding urban tourism economies, will find much scope for empirical enquiry by applying an evolutionary economic geography lens to urban tourism economies. 
This paper sets out the potential of applying evolutionary economic geography (EEG) (cf. Boschma and Martin 2010a) in studies of urban tourism, highlighting the concepts of co-evolution and complexity in contested urban spaces. In this paper, our principal aim is to examine the applications of EEG to urban tourism. We draw on recent studies of urban tourism, which utilise an evolutionary perspective, in order to highlight the possibilities of adopting such an approach, and we put forward a number of avenues yet to be explored. The paper concludes with a future research agenda for evolutionary approaches to studies of urban tourism, one that demands a holistic conceptualisation of the economic evolution of urban tourism economies.

\section{Economic Geography and Tourism—an Evolving Theoretical Framework?}

Economic geography attempts to understand the development of regional economies from a spatial perspective and examines the reasons behind the varying fortunes of regions. Simply put, economic geography seeks to comprehend why certain areas prosper while others do not. It also examines the economic restructuring of regions, offering explanations for their changing fortunes over time.

In the case of varying patterns of tourism development, in the past, these have been simplistically perceived as being the result of inherent locational advantages (e.g. a rich and diverse base of natural and human-built attractions as well as good connections to major markets). However, these factors only partially explain the long-term evolution of destinations. When it comes down to the level of the destination, there are both subtle change processes at play as well as major top-down investments, which can change the face of the destination in general and tourism in particular. Thus, it is necessary to analyse change processes at localised but multiple levels, including the firm level, the destination level and the regional level (cf. Haugland et al. 2011).

Ioannides (2006) calls for a more active, closer connection between tourism studies and economic geography with a view to finding new perspectives on change in tourism (see also Ioannides and Debbage 2014). One recent development in economic geography, which has received attention from tourism scholars, is EEG (cf. Brouder and Eriksson 2013b; Brouder 2013, 2014a). With its focus on the historical factors, which condition the future courses of regional development (Boschma and Martin 2010b), EEG draws attention to long-term, ongoing processes leading to change. EEG also highlights the heterodox nature of regional economies, with not one but many possible development paths present in a given region at any given time. Thus, Brouder (2014b) argues that EEG can help contribute towards understanding of tourism in regions where it is not the dominant sector, or where it is made up of multiple, possibly contesting, paths.

Papatheodorou (2004) demonstrated the position and action of peripheral players in mass tourism destinations and highlighted the interplay between market and spatial forces. As such, his was among the first studies to isolate the notion of spatial evolution of the tourism sector including the role of powerful conglomerates, such as international hotel chains and food services chains, who inevitably occupy the centre of the tourism system. EEG theory has created theoretical space to build on Papatheodrorou's work since "potential exists for studies to include the multiple, co-evolving, tourism development paths within a regional economy of multiple, co-evolving, non-tourism development paths" (Brouder and Eriksson 2013b: 374). Thus, tourism must not be 
conceptualised as a monolithic development path but rather as (an) internally contested and externally fractional development path(s).

In other words, there are both central actors and peripheral actors, each with their own (sometimes competing) goals, and they all operate in regions where many other actors with very different (non-tourism) goals are also operating. This is especially the case in the context of urban areas. Such a conceptualisation echoes the influential call of Milne and Ateljevic (2001) for a more rigorous understanding of the tourism economy, and while they highlight new economic geography approaches as being of particular interest, their call for embracing complexity is also well-matched to the recent emergence of evolutionary economic geography in tourism studies. One caveat, however, is that economic geography approaches have often been critiqued for failing to incorporate a political economy perspective (Bianchi 2009), and there has been some debate in EEG as to whether it can (or should) do more in this regard (cf. Essletzbichler 2009; MacKinnon et al. 2009).

It is worth noting that "tourism development has been spatially uneven within countries" (Rogerson and Visser 2007: 16). This in itself points to localised processes, which influence the development of certain sectors over others. It also forms a tangible foundation for questioning the sustainability of regions pursuing one development path, whether destinations are emerging or going through a period of gradual change. When new sectors emerge, there is a related change in the institutional structure of the region. New institutions emerge, old institutions are challenged and individuals with particular skill sets become marginalised while others become central and still others manage to adapt their skills to the new institutional reality (cf. Brouder and Eriksson 2013b). As a result of seemingly ever-increasing place competition, "the role of tourism has strengthened such that it represents an important policy issue for urban sustainable development" (Rogerson 2013: 189). Thus, urban environments constitute natural laboratories for studying the complex evolution of tourism alongside other development paths, and we argue that EEG emerges as a particularly useful theoretical framework.

EEG has been shown to offer a useful analytical approach towards understanding tourism development since it possesses several advantages (cf. Boschma and Martin 2010b; Essletzbichler 2012):

- EEG is focussed on economic issues but is open to broader definitions of development than purely monetary/financial conceptualisations of development.

- EEG is embedded in local conditions and is spatially sensitive while being operable at multiple scales and being concerned with long-term, gradual developments.

- EEG is related to innovation through its neo-Schumpeterian view on continuous reproduction of knowledge as central to change.

EEG highlights relational exchange through knowledge transfer but does not, however, limit this to interfirm exchanges. The role of the public sector has long been incorporated into evolutionary economics through the concept of innovation systems (Cooke 1992; Freeman 1987; Lundvall 1992; Malerba 2004). EEG maintains that change is ongoing and takes time. If a region is to change its industrial profile, it will do so over the long-term and any diversification will be conditioned by the related sectors available in the region (Neffke and Svensson Henning 2010). Thus, how exactly tourism emerges is open to further investigation. 


\section{EEG and Tourism Studies}

Within the extant studies of EEG and tourism "there are two main areas addressed: path dependence (and how to break from a path) and co-evolution (of tourism paths within a region and of regional paths including tourism)" (Brouder 2014b). Interestingly, contrary to more general studies on EEG with their overwhelming focus on urban agglomerations, most tourism studies utilising this perspective concentrate on rural areas (e.g. Brouder and Eriksson 2013a; Halkier and Therkelsen 2013; Larsson and Lindström 2014; Randelli et al. 2014; Brouder, P., \& Fullerton, C. Cascade effect or co-evolution in tourism in the Niagara region? Scandinavian Journal of Hospitality and Tourism, 15, in press). Meanwhile, the handful of tourism studies which have already utilised EEG in an urban context can be categorised into two groups: resort destinations (Gill and Williams 2011, 2014) and mass tourism centres (Ma and Hassink 2014; SanzIbáñez and Anton Clavé 2014). As yet, there have been no cases of EEG and tourism in metropolitan settings which, again, is somewhat puzzling in light of the important place metropolitan places hold in the general body of EEG research.

In a recent research note, Garcia-Cabrera and Duran-Herrera (2014) focus on the concept of co-evolution in Spanish mass tourism and highlight that entrepreneurs and institutions co-evolve when faced with the financial crisis. While the focus of their work is on the tourism industry, the financial crisis must also have led to co-evolution between tourism and other sectors of the regional economy (in Spain and elsewhere) as institutions adjusted to the economic shock and as certain stakeholders repositioned themselves in the regional economic system. For example, tourism and agriculture regained stature during the Irish economic crisis - agriculture has regained its historic prominence in the national economy (McWilliams 2014) and 2013 proved to be the most successful tourism year in almost a decade (Department of Transport, Tourism and Sport 2014). There is, thus, ample empirical material for studies of EEG and tourism whether the focus is on changes within tourism or changes in tourism's place within the wider economy. However, as GarciaCabrera and Duran-Herrera (2014) caution, there may be a time lag between external changes impacting the tourism system and changed behaviour of the tourism stakeholders. This has implications for research design, particularly in cases of shocks to the system.

Given that large urban areas tend to have a faster pace of change and a more diversified economy than other regions, there is great scope for studies of EEG and tourism in urban settings. Moreover, the changes in governance frameworks that have been dominant in the neoliberal era since the early 1980 s imply that urban tourism environments are becoming even more complex and, arguably, more contested. We now examine the changes in urban governance and the implications for urban tourism research.

\section{Evolutionary Change in the Neoliberal Era}

Since the early 1980s, the transformation of cities throughout the world has been linked to the rising dominance of neoliberal ideology, which has resulted, for instance, in the reduction of the Keynesian welfare state, and the redirection of governance responsibilities from government at all levels towards public-private initiatives (Brenner and Theodore 2002; Peck and Tickell 2002). An outcome of this rise in neoliberalism has 
been that cities have often been forced to become more entrepreneurial than ever before, embarking on projects that emphasise their competitiveness in the global arena. As such, pursuing visitors in order to strengthen cities' economies and transform them into desirable places to live has become a particularly important narrative of the contemporary era (Judd 2004; Hall 2006; Ioannides, D., \& Petridou E. Contingent neoliberalism and urban tourism in the United States. In J. Mosedale (Ed.) Neoliberalism and tourism: projects, discourses and practices. London: Ashgate, in press). Interestingly, such strategies have not been solely restricted to metropolitan regions in advanced economies. Rather, the proliferation of large-scale investments with a tourist twist, such as the ones witnessed in South African cities like Johannesburg, Durban and Cape Town (Rogerson 2013) as well as Dubai (Henderson 2006), that arise from entrepreneurialism and the pursuit of foreign direct investment have been a major reflection of the rising global dominance of neoliberal solutions to regional growth.

A significant point of discussion concerning neoliberalism is that it has been static in neither time nor space. In other words, although many observers have been quick to dismiss the proliferation of downtown redevelopment projects and the enticement of major events as a reflection of the dominance of neoliberal ideology and the associated globalisation of culture (Owens 2008), they fail to acknowledge that neoliberalism itself has continually evolved from its initial proto/rollback guise of the early 1980 s through to its roll-out/revanchist identity of the 1990s and early 2000s to what some observers argue has been its impending demise resulting from the global financial crisis of recent years (Smith 2009; Brenner et al. 2010). Moreover, they tend to ignore that neoliberalism is not a one-size-fits-all approach but, in fact, is highly contingent in a spatial sense (Wilson 2004; Hackworth 2007) since it plays out differently from place to place. This means they fail to account for the "contextual embeddedness of neoliberal restructuring projects insofar as they have been produced within national, regional, and local contexts defined by the legacies of inherited institutional frameworks, policy regimes, regulatory practices, and political struggles" (Brenner and Theodore 2002: 351).

In particular, the argument by Brenner et al. (2010: 327) that neoliberalisation appears "as a variegated, geographically uneven and path-dependent process" [emphasis added] has direct relevance for examining urban tourism and how it plays out in various contexts through the EEG lens. Thus, for example, it would be useful to comprehend how ever-evolving urban governance structures form and implement strategies that directly and indirectly influence tourism development within a sustainability context (Gill and Williams 2014). Alternatively, EEG could offer a useful perspective when seeking to comprehend shifts in the urban tourism terrain and breaks in path dependency that emerge in the aftermath of social and economic crises such as those that have plagued Greece in recent years (Ioannides, D., \& Petridou E. Contingent neoliberalism and urban tourism in the United States. In J. Mosedale (Ed.) Neoliberalism and tourism: projects, discourses and practices. London: Ashgate, in press).

Finally, the adoption of an EEG framework within the scope of urban tourism is useful for strengthening scholarship that synchronises tourism research with critiques of neoliberalism, a subject which Hall and Page (2012) believe is of paramount importance in human geography. Rogerson (2013: 189) makes a salient point here regarding research on "shared growth" in South African cities, especially Cape Town, Durban and Johannesburg. While control in the tourism industry in these destinations is highly concentrated in the hands of large corporations, inadequate attention has been paid to 
SMEs, which in sheer numbers make up the vast majority of tourism businesses. In turn, this lack of attention means that the position, for example, of black entrepreneurs in the industry, especially those involved in township tourism, has not been explored in depth. The adoption of an EEG lens would allow researchers to view the SMEs associated with the various market segments as representing tourism development paths, which are distinct from those of corporate development firms, and explore their interplay from there. Furthermore, the interconnection of these tourism-oriented trends with those of sectors and institutions not directly linked to the industry could also be identified and further developed. For instance, the link between the creative economy and the tourism economy is well-established (Richards and Wilson 2007), and this is now being extended to link creative tourism with alternative tourism (Richards and Russo 2014).

\section{Urban Tourism and Evolutionary Economic Geography}

From an EEG perspective, knowledge is constantly being produced and reproduced and the ongoing transfer and utilisation of this knowledge leads to changes in long-term regional economic development. EEG conceptualises "economic geography as dealing with the uneven distribution of economic activity across space. An evolutionary approach specifically focuses on the historical processes that produce these patterns" (Boschma and Frenken 2011: 296). Thus, by studying the local innovation processes, which lead to change within the tourism economy of a region, it is possible to see how tourism becomes embedded in certain locales while remaining tentative or underdeveloped in others. With its focus on long-term, incremental evolution, EEG also makes it feasible to focus on areas which are not the classic success stories, including urban areas where tourism is not the economic mainstay of the place but, at different times, has been, or may become, a significant part of the local economy.

Rogerson and Rogerson (2014) have shown divergent urban tourism development pathways in eight metropolitan areas of South Africa by comparing the changes in market segments (e.g. business, leisure, domestic, international, VFR) in each large urban centre. Without a doubt, each segment has a related group of entrepreneurs and institutions, which become the localised winners and losers as patterns of travel change. Rogerson and Rogerson (2014) call for more local-level studies to fully investigate these divergent trends, and we hold that EEG can claim its stake as an appropriate theoretical frame through which to analyse trends in South African cities but also other large urban centres and metropolitan regions globally.

One challenge in tourism studies relating to economic change is whether the tourism sector or the regional economy should be given primacy. An evolutionary perspective treats tourism development as one path (or perhaps several paths) co-evolving alongside other sectoral paths in the regional economy. Tourism development paths in urban settings could atrophy over time even if they have demonstrated success at various levels in previous years. Additionally, completely new paths are likely to emerge in a region and may challenge the existing economic focus (e.g. the IT sector boom in Dublin, Ireland, in the 1990s). Thus, the microprocesses relating to tourism development need to be examined more closely in order to see how embedded the tourism economy is in the wider regional economy. Rogerson and Visser (2011: 84) see urban 
tourism as "a critical aspect of the larger South African tourism economy... in the future further growth and significant expansion is likely to occur." This distinction at least highlights that cities in the global South have very different tourism development trajectories to their global North counterparts and that this is an important area of growth in the coming decades. Following this, the relationship between urban tourism and urban poverty needs to be examined further since rapidly urbanising societies present a strong rationale for focusing poverty alleviation research in tourism on the urban centres of the global South (Rogerson and Visser 2011). The challenge of studying EEG and urban tourism is warranted, given the importance of urban centres in the twenty-first century and the potential of an EEG lens to better understand the existing and emerging urban diversity.

How scholars researching EEG and tourism define development will have a direct impact on how they conceptualise pro-poor tourism development with the South African case a challenge to scholars to include broader definitions of development than purely economic ones. Moving beyond a global North-centric perspective may ultimately lead to reassessing research in the global North where "boosterist" discourses of urban tourism development still dominate (cf. Rogerson and Visser 2011: 85). Thus, the extant literature on urban tourism encourages greater conceptual engagement with EEG in order to address the theoretical development of both EEG and urban tourism.

\section{EEG and Urban Tourism: an Emerging Research Agenda?}

In recent years, evolutionary economic geography (EEG) has been applied to various tourism cases (cf. Brouder 2014b). However, relatively few have focused on urban settings. This is somewhat incongruous with EEG studies in general, which have mostly focused on large urban centres. The urban economic environment itself is a rich empirical field due to its inherent complexity, and as urbanisation and counterurbanisation processes continue, cities will increasingly be important places when it comes to the challenge of achieving sustainable development (Rogerson 2013; Rogerson and Visser 2011). EEG is conceptually broad enough to challenge growthcentric approaches in urban tourism research since "there is no a priori reason to suggest that [capitalist markets are] optimising or cannot be changed to obtain alternative goals... In this sense, evolutionary theory can evolve into a scientifically and socially progressive research programme." (Essletzbichler 2012: 143). While the general scope of EEG is quite broad, we have selected a number of important and actionable research themes in urban tourism studies which would benefit from an EEG perspective. The list is not exhaustive but rather it is a first step in stimulating research on EEG and urban tourism.

1. Co-evolution of urban tourism firms with the public sector and NGOs: Gill and Williams $(2011,2014)$ have already contributed work relating to these issues, especially the manner in which governance strategies evolve through time in the context of the Canadian winter tourism resort of Whistler. It seems only natural to expand this work to examine large urban areas where tourism is only one of many development paths. It would be especially interesting, for instance, to investigate 
how, in the face of global economic crises and the rise of urban resistance movements (e.g. the crisis that has had particularly brutal outcomes in southern Europe), cities are often forced to break out of their path-dependent governance models. This, in turn, may trigger new approaches to tourism development and marketing while at the same time other actors (e.g. tourism companies and NGOs) seek out novel ways to portray the city, which extend beyond the status quo of culturally driven strategies (cf. Richards and Wilson 2007).

2. Beyond mega-projects and cultural tourism solutions: The work by Richards and Wilson (2007) itself points to the fact that many cities are beginning to explore avenues beyond the predictable neoliberal emphasis on the staging of mega-events. City centre transformation now includes projects designed to lure cultural visitors and is somewhat closer to local stakeholders, albeit with certain cultural elites driving change. Investigations of such transformation through an EEG lens could include, for instance, analysing the triggers leading to an escape from pathdependent actions of tourism stakeholders towards the creation of new paths. The role of agents not normally seen as being directly related to tourism, like artists (e.g. street artists) and movements such as guerrilla garden projects, indirectly lead to new forms of tourism in areas beyond the traditional tourism enclaves and are seldom-studied stakeholders.

3. Evolution of the informal economy: As numerous metropolitan regions, for instance, are rapidly transformed into globalised hubs with immigrants of many nationalities, there is often a rise of informal economies, which are especially dominant in the parts of the city where these individuals tend to gravitate. Often these are zones of exclusion, parts of the city resting outside the areas that the neoliberal projects seek to protect, and as such, they offer the potential for new forms of visitor-related activities and can be very innovative. Once more, the network of actors influencing the fortunes of these zones and the manner in which they contribute towards new path development that affects the development of tourism and local well-being are worthy of empirical investigation even though they fall outside of traditional tourism metrics.

4. Networking and knowledge transfer in dense urban environments: Ashworth and Page (2011) highlighted that cities are multifunctional entities where tourism becomes almost invisible. That being said, cities also offer a unique perspective on tourism networks since there are more opportunities for interaction with related sectors. Richards and Wilson (2007) have shown that tourism has much interaction with the creative sectors and the potential for this is greatest in urban contexts even if it is also harder to realise this potential because of competing interests and financial pressure. In any case, studies of knowledge transfer in urban contexts, which draw on EEG theory and the existing rural case studies (e.g. Larsson and Lindström 2014), will reveal the nature and extent of intra- and extra-urban tourism networking and will elaborate on the role this plays in the evolution of urban destinations going forward.

5. Path dependence and new path creation: Gill and Williams (2011) have shown path dependence to be present in their case of the resort community of Whistler and also that local stakeholders can create a new, more sustainable path, through a process of "mindful deviation" (Gill and Williams 2014). Thus, there already exists a blueprint for studies of new path creation in large urban contexts. Urban tourism 
is an important element in general sustainable development (Rogerson 2013). How exactly urban stakeholders develop tourism in an inclusive and sustainable manner will be one of the most important points of study by urban tourism scholars in the years ahead.

6. Contribution of new tourism firms to regional branching: As tourism continues to expand its reach across the globe, it is emerging in and spreading through more and more urban centres, particularly in the global South. Building on studies of, for example, the informal economy and urban tourism enclaves, it will be possible to trace the long-term evolution of the local geography of tourism as it permeates even more urban communities. Branching implies taking knowledge from other geographical contexts and from other related sectors and applying it in a new context. Urban tourism is a genuine empirical goldmine for studies elaborating on mechanisms of urban change as grassroots economic developments appeal to many tourists.

The above are only a handful of possible research areas, which could fuel the application of EEG to urban tourism. Certainly, as inquiries into these areas gather steam, they will lead to even more areas of exploration relating to this topic. It is our sincere hope that through this article, we can inspire geographers and other researchers who investigate the dynamics of tourism to expand the focus of their attention on tourism development paths in urban regions.

\section{References}

Ashworth, G., \& Page, S. J. (2011). Urban tourism research: recent progress and current paradoxes. Tourism Management, 32(1), 1-15.

Beauregard, R. (1998). Tourism and economic development policy in US urban areas. In D. Ioannides \& K. G. Debbage (Eds.), The economic geography of the tourist industry: a supply-side analysis (pp. 220-234). London: Routledge.

Bianchi, R. (2009). The 'critical' turn in tourism studies: a radical critique. Tourism Geographies, 11(4), 484 504.

Boschma, R., \& Frenken, K. (2011). The emerging empirics of evolutionary economic geography. Journal of Economic Geography, 11(2), 295-307.

Boschma, R., \& Martin, R. (2010a). The handbook of evolutionary economic geography. Cheltenham: Edward Elgar.

Boschma, R., \& Martin, R. (2010b). The aims and scope of evolutionary economic geography. In R. Boschma \& R. Martin (Eds.), The handbook of evolutionary economic geography (pp. 3-39). Cheltenham: Edward Elgar.

Brenner, N., \& Theodore, N. (2002). Preface: from the "new localism" to the spaces of neoliberalism'. Antipode, 34(3), 341-347.

Brenner, N., Peck, J., \& Theodore, N. (2010). After neoliberalization? Globalizations, 7(3), 327-345.

Brouder, P. (2013). Tourism development in peripheral areas: processes of local innovation and change in Northern Sweden. Östersund: Mid Sweden University.

Brouder, P. (2014a). Evolutionary economic geography: a new path for tourism studies? Tourism Geographies, 16(1), 2-7.

Brouder, P. (2014b). Evolutionary economic geography and tourism studies: extant studies and future research directions. Tourism Geographies, 16 (4).

Brouder, P., \& Eriksson, R. H. (2013a). Staying power: what influences micro-firm survival in tourism? Tourism Geographies, 15(1), 124-143. 
Brouder, P., \& Eriksson, R. H. (2013b). Tourism evolution: on the synergies of tourism studies and evolutionary economic geography. Annals of Tourism Research, 43, 370-389.

Cooke, P. (1992). Regional innovation systems: competitive regulation in the New Europe. Geoforum, 23, 365-382.

Department of Transport, Tourism and Sport (2014). Record year for tourists from North America \& best year for overall tourism since 2008. www.dttas.ie/tourism.

Essletzbichler, J. (2009). Evolutionary economic geography, institutions, and political economy. Economic Geography, 85(2), 159-165.

Essletzbichler, J. (2012). Generalized Darwinism, group selection and evolutionary economic geography. Zeitschrift für Wirtschaftsgeographie, 3, 122-146.

Fainstein, S. S., Hoffman, L. M., \& Judd, D. R. (2004). Introduction. In L. M. Hoffman, S. S. Fainstein, \& D. R. Judd (Eds.), Cities and visitors: regulating people, markets, and city space (pp. 1-19). Oxford: Blackwell.

Freeman, C. (1987). Technology policy and economic performance: lessons from Japan. London: Pinter.

Garcia-Cabrera, A. M., \& Duran-Herrera, J. J. (2014). Does the tourism industry co-evolve? Annals of Tourism Research, 47, 81-83.

Gill, A. M., \& Williams, P. W. (2011). Rethinking resort growth: Understanding evolving governance strategies in Whistler, B.C. Journal of Sustainable Tourism, 19(4-5), 629-648.

Gill, A.M., \& Williams, P.W. (2014). Mindful deviation in creating a governance path towards sustainability in resort destinations. Tourism Geographies, 16 (4).

Gotham, K. F. (2006). Theorizing urban spectacle. City, 9(2), 225-246.

Hackworth, J. (2007). The neoliberal city: governance, ideology, and development in American urbanism. Ithaca: Cornell University Press.

Halkier, H., \& Therkelsen, A. (2013). Exploring tourism destination path plasticity: the case of coastal tourism in North Jutland, Denmark. Zeitschrift für Wirtschaftsgeographie, 57(1-2), 39-51.

Hall, C. M. (2006). Urban entrepreneurship, corporate interests and sports mega-events: the thin policies of competitiveness within the hard outcomes of neoliberalism. Sociological Review, 52(S2), 59-70.

Hall, C. M., \& Page, S. J. (2012). From the geography of tourism to geographies of tourism. In J. Wilson (Ed.), The routledge handbook of tourism geographies (pp. 9-25). London: Routledge.

Haugland, S., Ness, H., Grønseth, B.-O., \& Aarstad, J. (2011). Development of tourism destinations: an integrated multilevel perspective. Annals of Tourism Research, 38(1), 268-290.

Henderson, J. C. (2006). Tourism in Dubai: overcoming barriers to destination development. International Journal of Tourism Research, 8, 87-99.

Hoffman, L. M., Fainstein, S. S., \& Judd, D. R. (Eds.). (2004). Cities and visitors: regulating people, markets, and city space. Oxford: Blackwell.

Ioannides, D. (2006). The economic geography of the tourist industry: ten years of progress in research and an agenda for the future. Tourism Geographies, 8(1), 76-86.

Ioannides, D., \& Debbage, K. G. (1998). The economic geography of the tourist industry: a supply-side analysis. London: Routledge.

Ioannides, D., \& Debbage, K. G. (2014). Economic geographies of tourism revisited: from theory to practice. In A. A. Lew, C. M. Hall, \& A. M. Williams (Eds.), The Wiley Blackwell companion to tourism (pp. 107119). Oxford: Wiley Blackwell.

Judd, D. R. (2004). Visitors and the spatial ecology of the city. In L. Hoffman, S. Fainstein, \& D. Judd (Eds.), Cities and visitors: regulating people, markets, and city space (pp. 23-38). Oxford: Blackwell.

Judd, D. R., \& Fainstein, S. S. (1999). The tourism city. New Haven: Yale University Press.

Larsson, A., \& Lindström, K. (2014). Bridging the knowledge-gap between the old and the new: regional marine experience production in Orust, Västra Götaland, Sweden. European Planning Studies, 22(8), 1551-1568.

Lundvall, B. Å. (Ed.). (1992). National systems of innovation: towards a theory of innovation and interactive learning. London: Pinter.

Ma, M., \& Hassink, R. (2014). Path dependence and tourism area development: The case of Guilin, China. Tourism Geographies, 16 (4).

MacKinnon, D., Cumbers, A., Pike, A., Birch, K., \& McMaster, R. (2009). Evolution in economic geography: institutions, political economy, and adaptation. Economic Geography, 85(2), 129-150.

Malerba, F. (Ed.). (2004). Sectoral systems of innovation. Cambridge: Cambridge University Press.

McWilliams, D. (2014). Tech industry looks good on paper-but agriculture is the lifeblood of our economy. Irish Independent (Sep 25th 2014), www.davidmcwilliams.ie/2014/09/25. 
Milne, S., \& Ateljevic, I. (2001). Tourism, economic development and the global-local nexus: theory embracing complexity. Tourism Geographies, 3(4), 369-393.

Neffke, F., \& Svensson Henning, M. (2010). Seeds of structural change. The role of entrepreneurs and expanding firms in shaping local path dependencies. Rotterdam: Erasmus Research Institute of Management.

Owens, L. (2008). From tourists to anti-tourists to tourist attractions: the transformation of the Amsterdam squatters' movement. Social Movement Studies, 7(1), 43-59.

Page, S. J. (1995). Urban tourism. London: Routledge.

Papatheodorou, A. (2004). Exploring the evolution of tourism resorts. Annals of Tourism Research, 31(1), 219-237.

Peck, J., \& Tickell, A. (2002). Neoliberalizing space. Antipode, 34(3), 380-404.

Randelli, F., Romei, P., \& Tortora, M. (2014). An evolutionary approach to the study of rural tourism. Land Use Policy, 38, 276-281.

Richards, G., \& Russo, P. (2014). Alternative and creative tourism. Arnhem: ATLAS.

Richards, G., \& Wilson, J. (Eds.). (2007). Tourism, creativity and development. London: Routledge.

Rogerson, C. M. (2013). Urban tourism, economic regeneration and inclusion: evidence from South Africa. Local Economy, 28(2), 188-202.

Rogerson, C. M., \& Rogerson, J. M. (2014). Urban tourism destinations in South Africa: divergent trajectories 2001-2012. Urbani Izziv, 25(Supplement), S189-S203.

Rogerson, C. M., \& Visser, G. (2007). Tourism research and urban Africa: the South African experience. In C. M. Rogerson \& G. Visser (Eds.), Urban tourism in the developing world: the South African experience (pp. 13-40). New Brunswick: Transaction.

Rogerson, C. M., \& Visser, G. (2011). Rethinking South African urban tourism research. Tourism Review International, 15(1/2), 77-90.

Sanz-Ibáñez, C., \& Anton Clavé, S. (2014). The evolution of destinations: towards an evolutionary and relational economic geography approach. Tourism Geographies, 16 (4).

Smith, N. (2009). The revolutionary imperative. Antipode, 4, 50-65.

Tufts, S. (2006). We make it work: the cultural transformation of hotel workers in the city. Antipode, 38(2), 350-373.

Wilson, D. (2004). Toward a contingent urban neoliberalism. Urban Geography, 25(8), 771-783.

Zampoukos, K., \& Ioannides, D. (2011). The tourism labour conundrum: agenda for new research in the geography of hospitality workers. Hospitality and Society, 1(1), 25-45. 